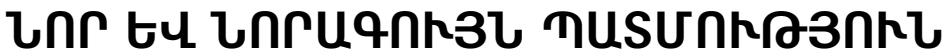

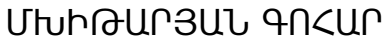

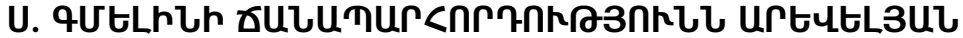

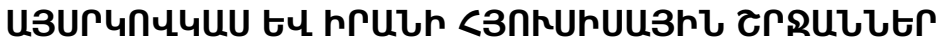

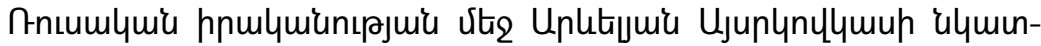

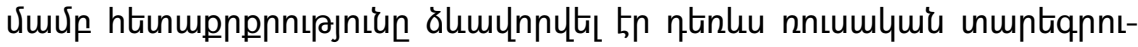

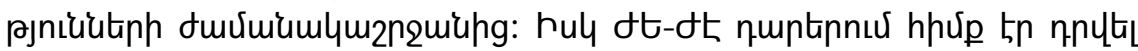

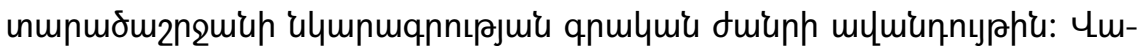

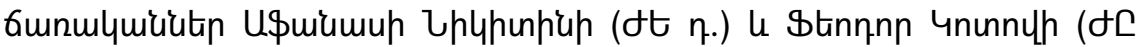

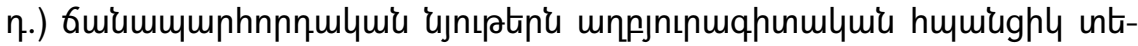

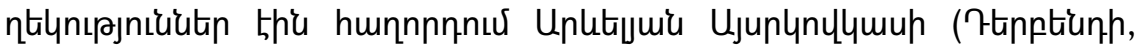

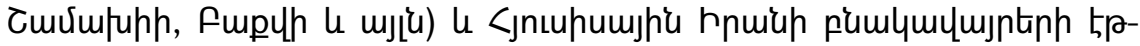

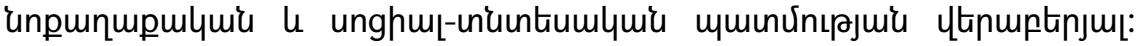

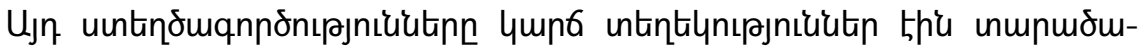

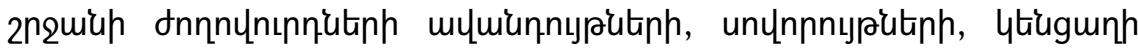

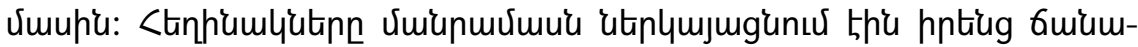

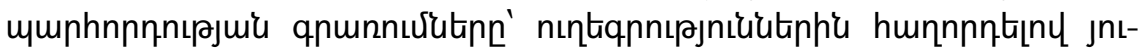
nuıntumly ătnüumply-nıntggnıgh punıjp:

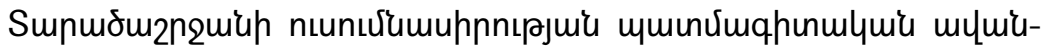

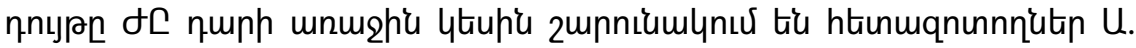

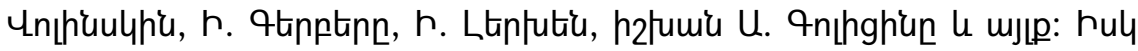

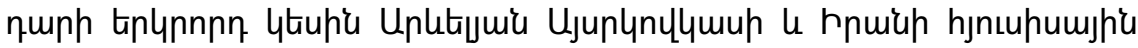

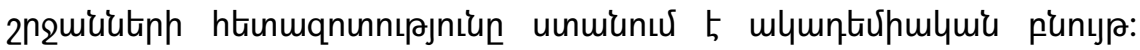

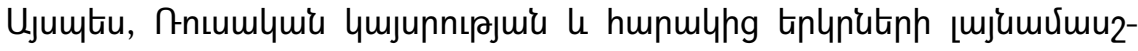

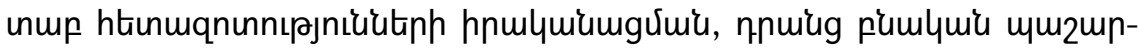

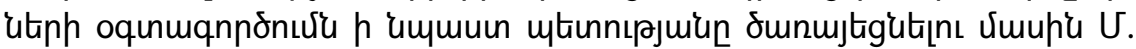
Lnưnununyh (1711-1765 рр.) unmqunnud ptqting 1768-1774 ра.

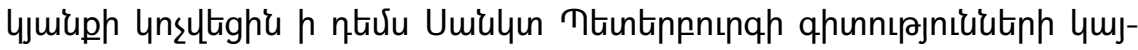

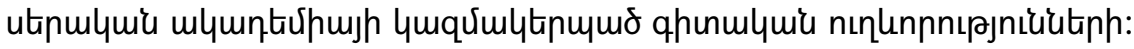




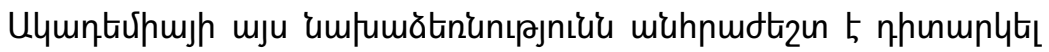

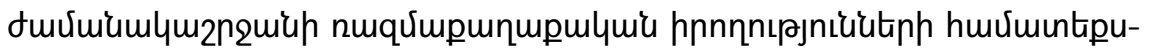

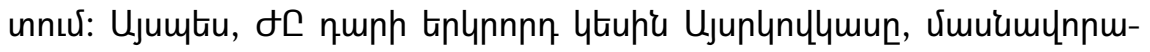

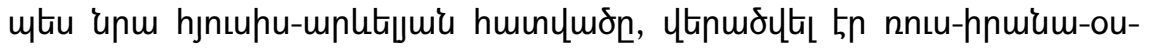

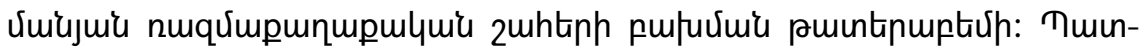

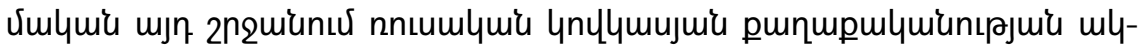

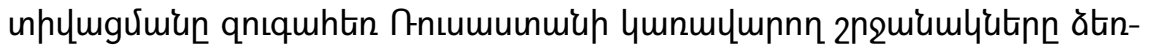

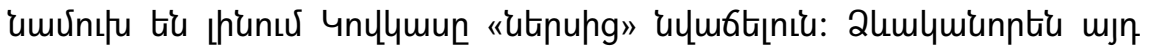

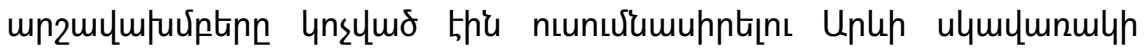

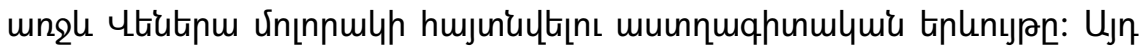

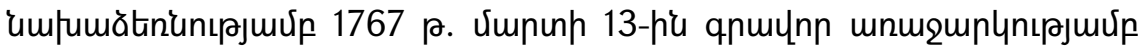

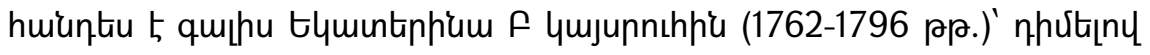

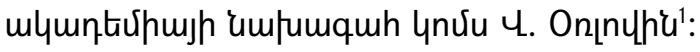

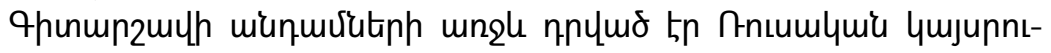

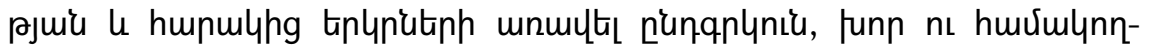

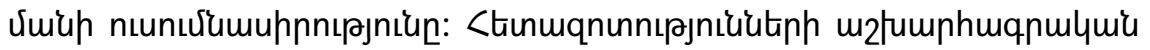

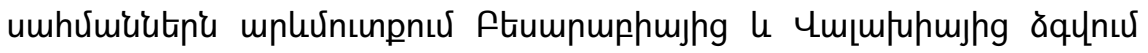

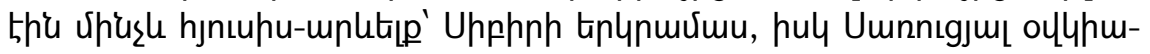

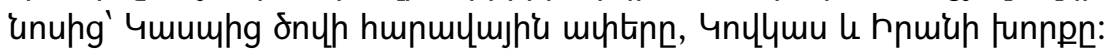

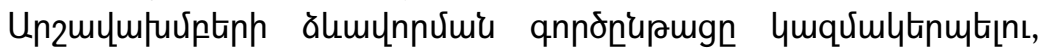

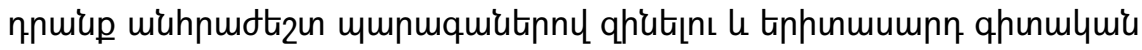

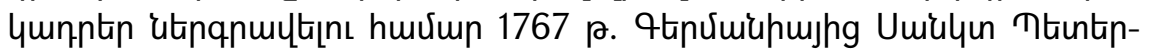

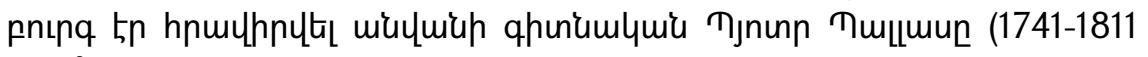

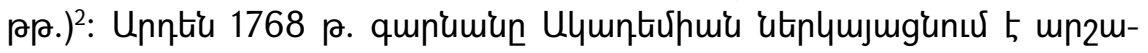

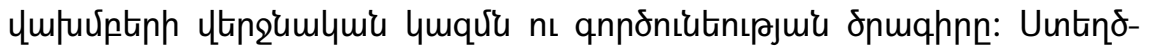

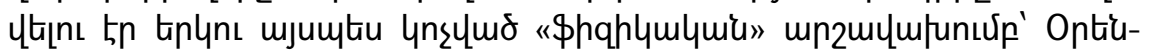

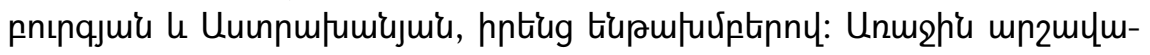

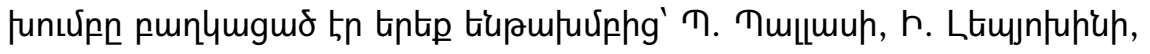

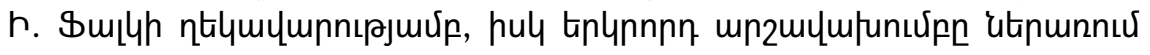

\footnotetext{
1 Наблюдения явления Венеры в Солнце в российской империи в 1769 году учинением с историческим предуведомлением, сочиненным Степаном Румовским, СПб, 1771, стр. 5-6.

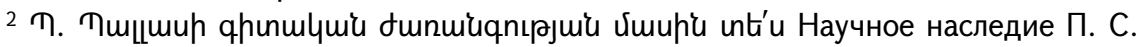
Палласа, Письма. 1768-1774 гг., сост. В. И. Осипов, СПб., 1993.
} 


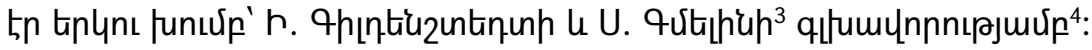

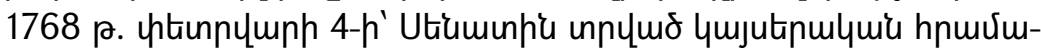

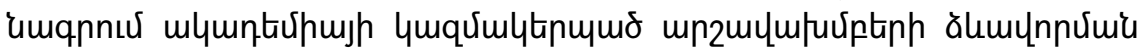

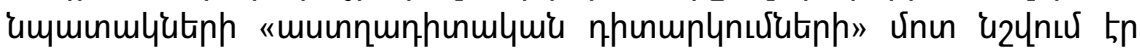

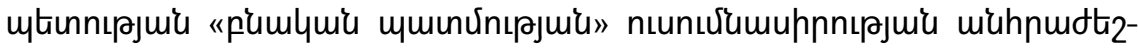

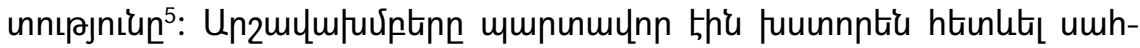

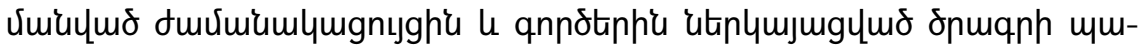

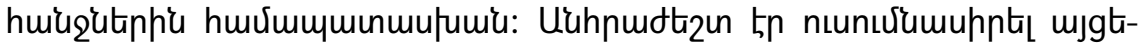

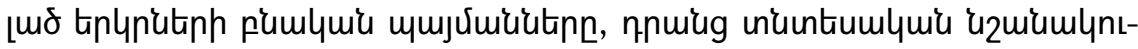

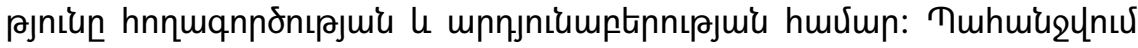

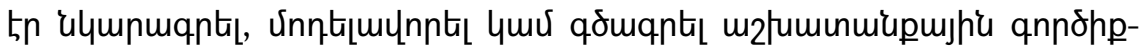

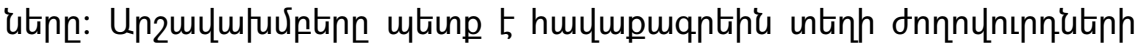

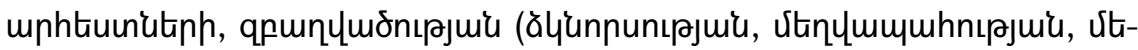

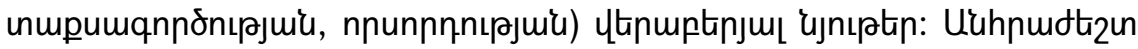

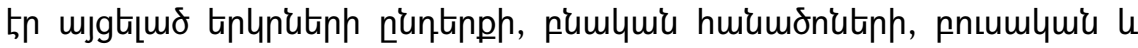

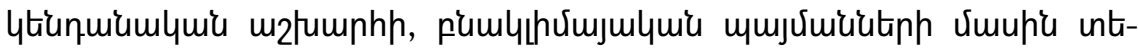

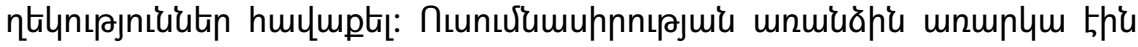

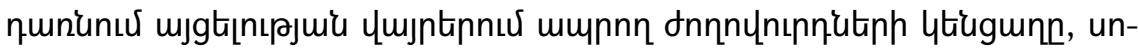

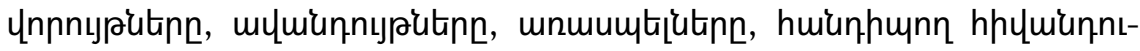

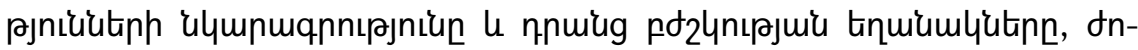

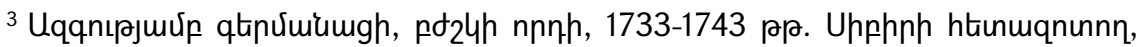

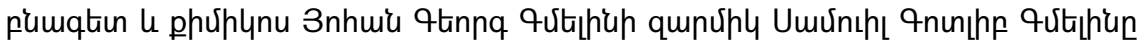

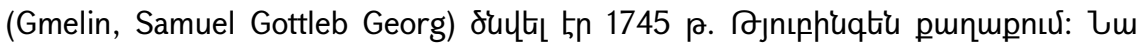

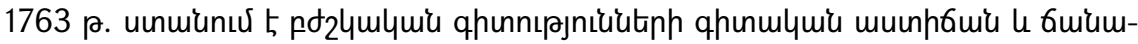

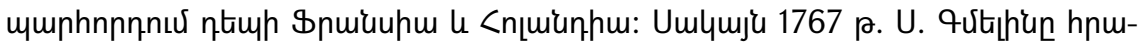

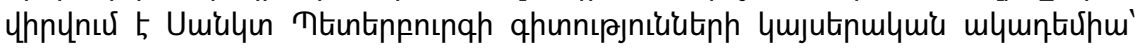

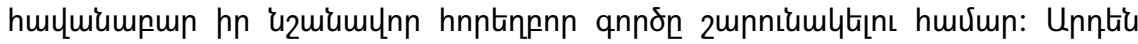

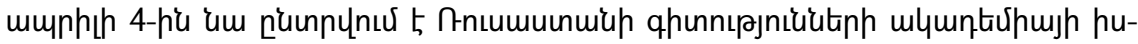

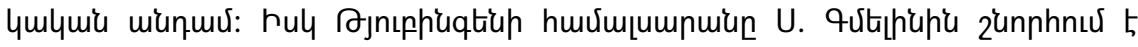

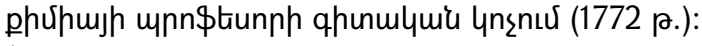

4 История российской академии, Соч. И. М. Сухомлинова, вып. 2, СПб., 1875, стр. 64.

${ }^{5}$ Наблюдения явления Венеры в Солнце в российской империи в 1769 году учинением с историческим предуведомлением, сочиненным Степаном Румовским, СПб, 1771, стр. 25. 


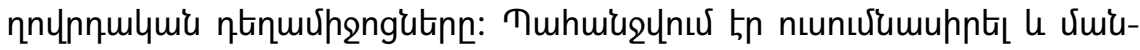

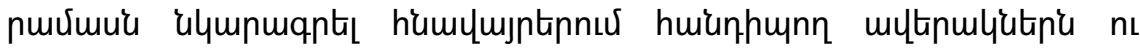

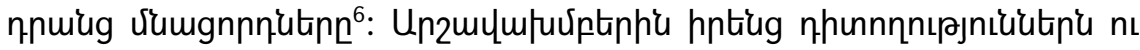

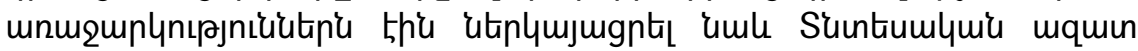

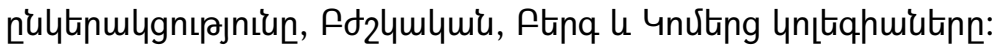

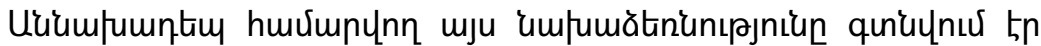

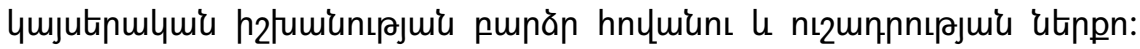

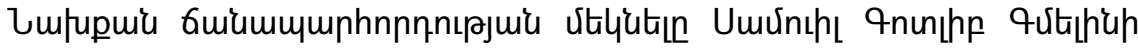

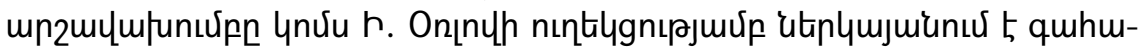

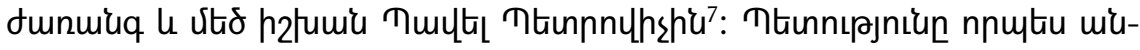

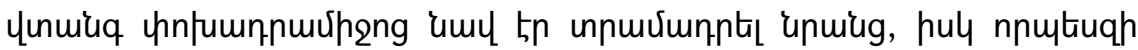

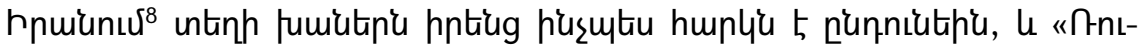

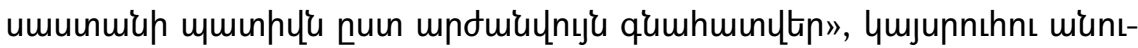

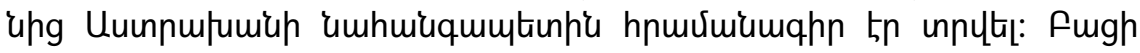

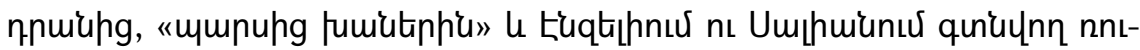

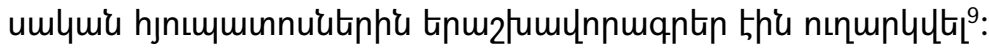

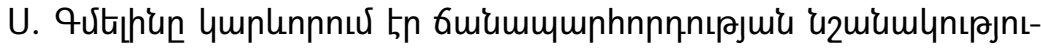

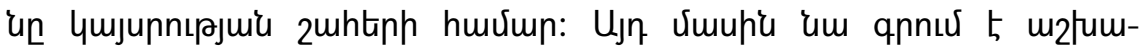

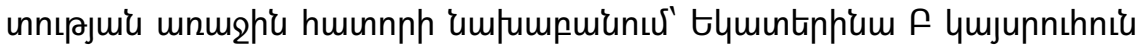

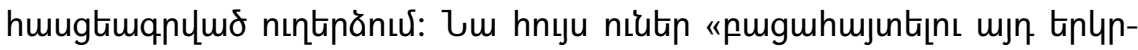

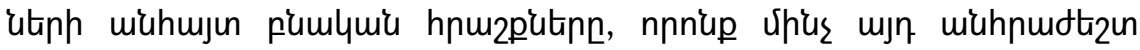

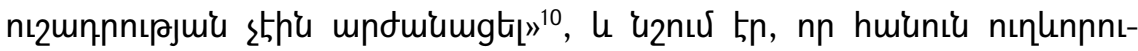

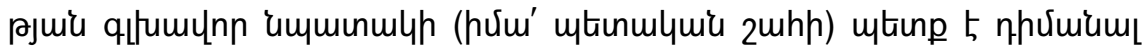

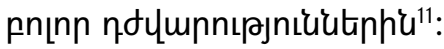

6 Фрадкин Н. "Инструкция для академических экспедиций 1768-1774 гг. Вопросы географии". Сб. 17, Москва, 1950, стр. 216-217.

7 Гмелин С. "Путешествие по России для исследования трех царств естества", часть І, СПб., 1771, стр. 1.

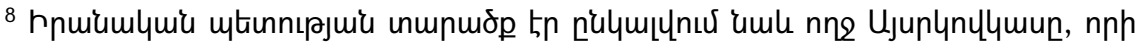

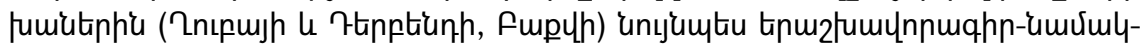
utip thic unnltil:

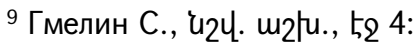

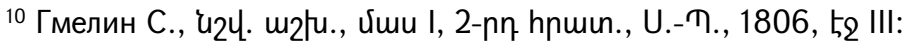

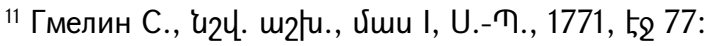




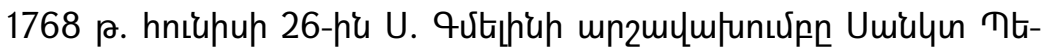

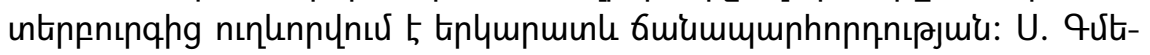

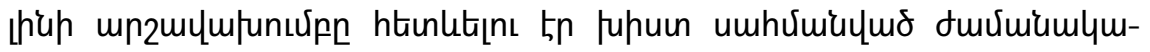

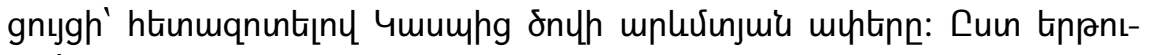

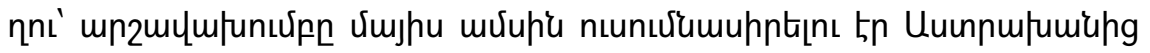

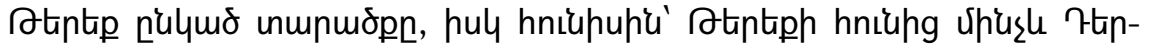

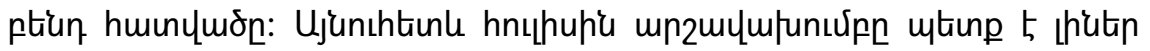

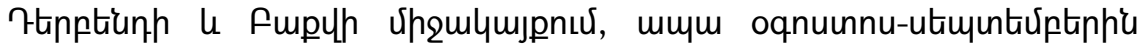

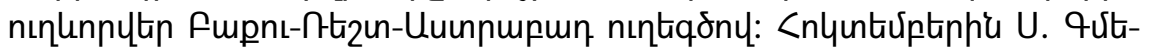

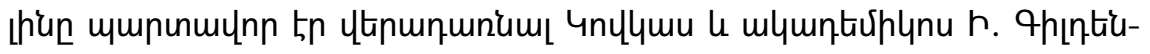

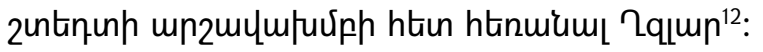

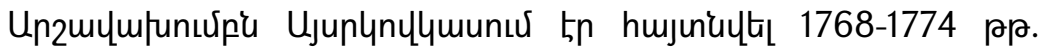

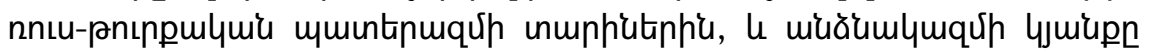

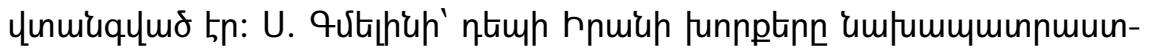

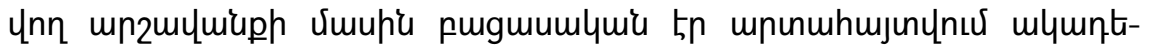

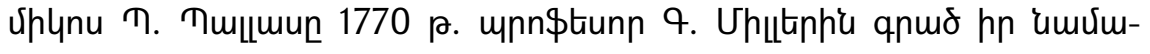

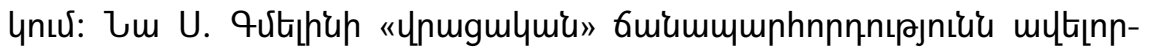

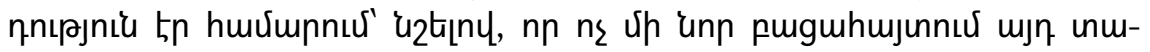

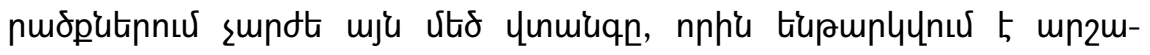

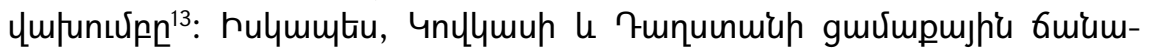

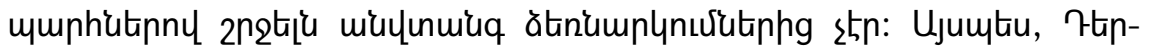

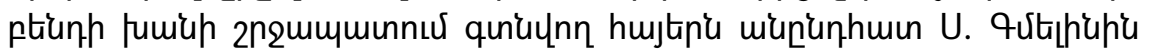

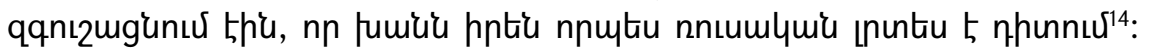

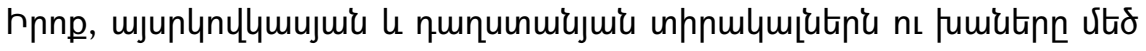

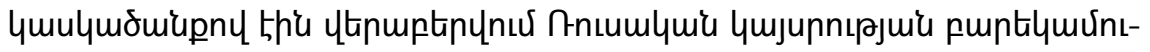

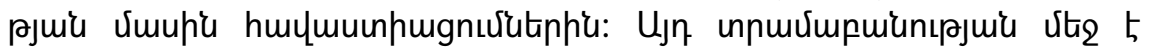

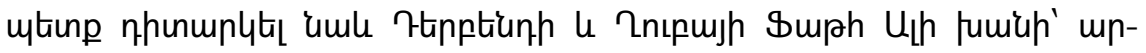

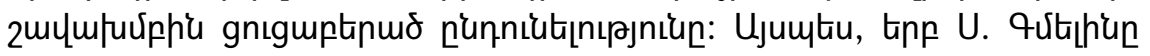

\footnotetext{
12 Гмелин С. "Путешествие по России для исследования трех царств естества", часть III, половина I, СПб., 1785, стр. 2-3.

${ }^{13}$ Научное наследие П.С. Палласа. Письма. 1768-1771 гг., Составитель В. И. Осипов, СПб., 1993, стр. 111.

${ }^{14}$ Гмелин С. "Путешествие по России для исследования трех царств естества", часть III, половина І, стр. 44.
} 


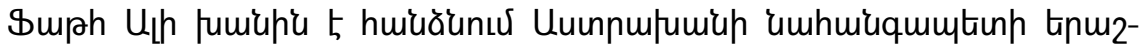

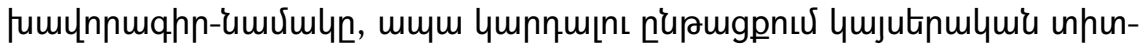

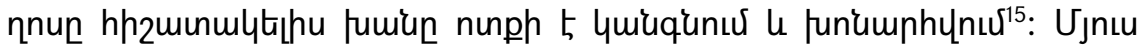

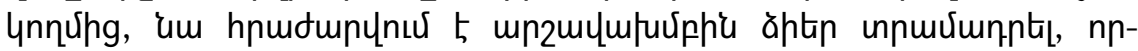

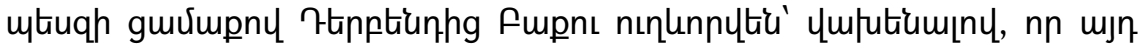

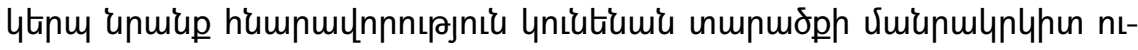

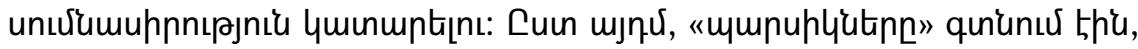

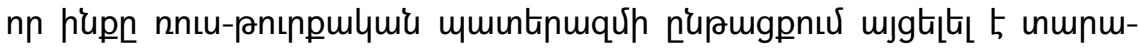

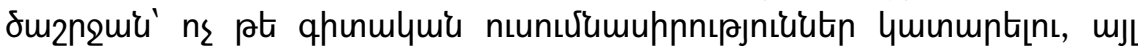

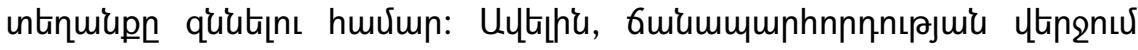

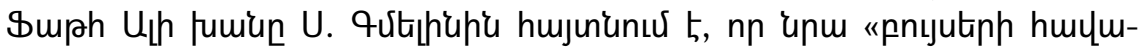

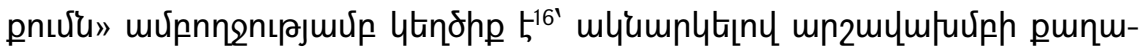
pulqui kumunulyitiph umupu:

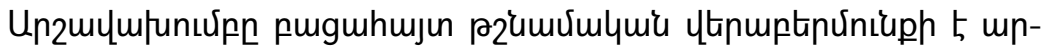

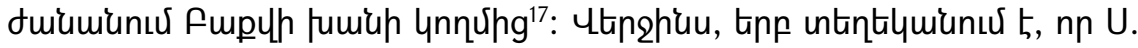

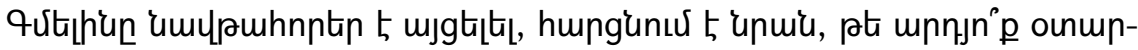

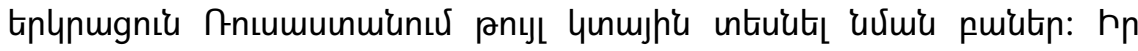

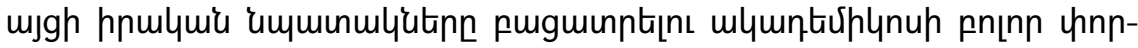

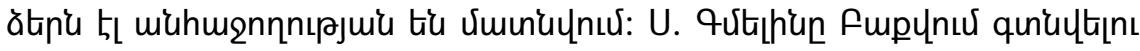

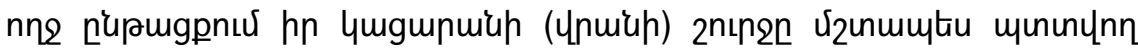

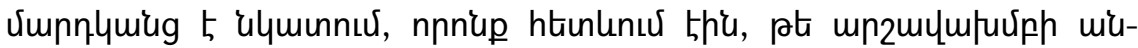

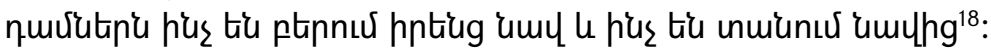

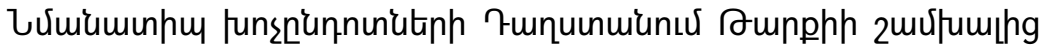

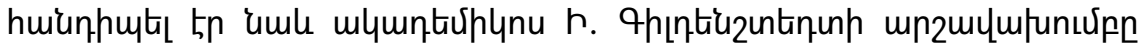
1770-mlumi pululumulitiphi ${ }^{19}$ :

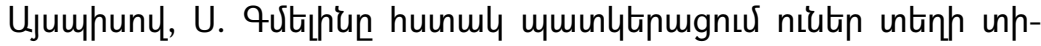

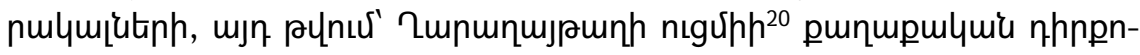

\footnotetext{
15 Unyju untinnux, to 11:

16 Unıృ untnnuu, 52 42-44, 109:

17 Unı'u untinnư, t5 61, 62:

18 unıju untnnuर, 5277 :

${ }^{19}$ Гюльденштедт И. "Географическое и статистическое описание Грузии и Кавказа, из путешествия через Россию и по Кавказским горам в 1770-1773", СПб., 1809, стр. 116-117.
} 


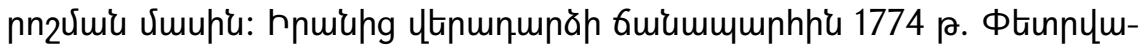

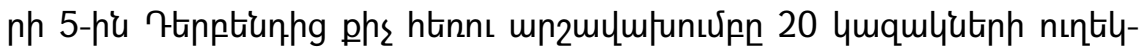

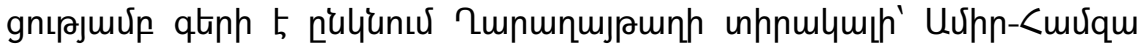

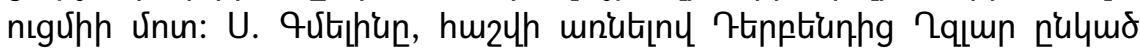

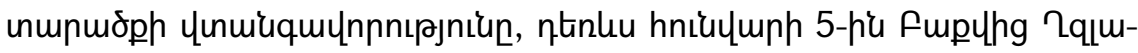

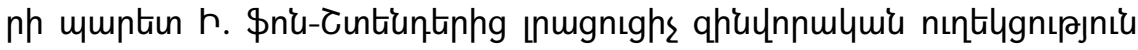

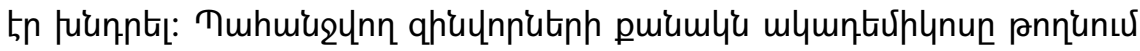
th muntiun hujtgnnnıрjuiun ${ }^{21}$ :

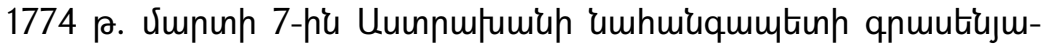

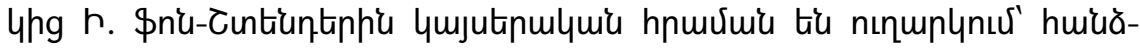

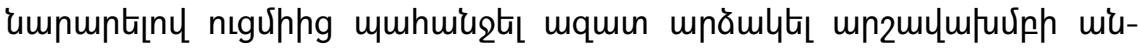

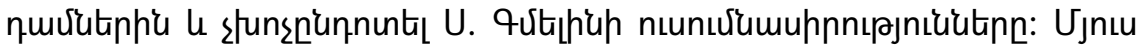

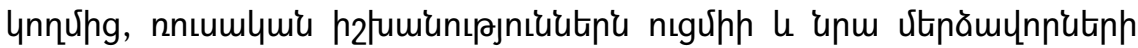

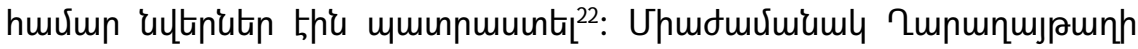

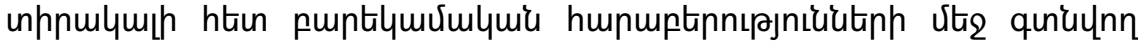

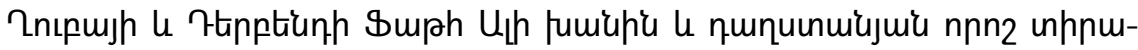

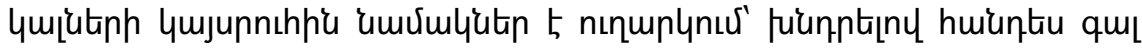

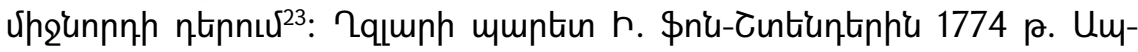

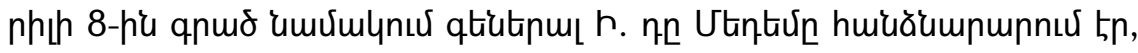

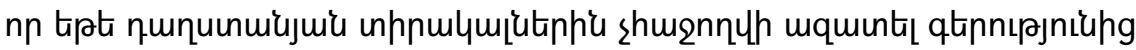

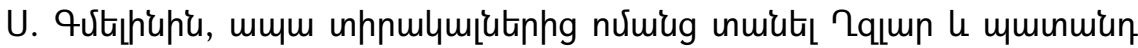
umbit, $\left.\right|^{24}$ :

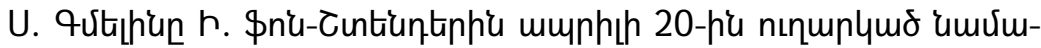

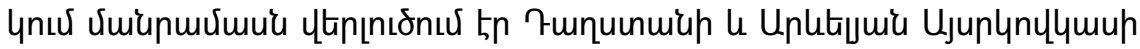

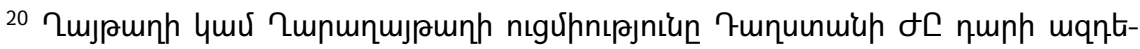

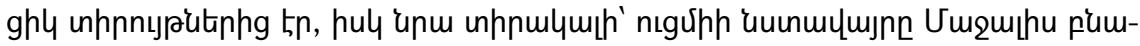

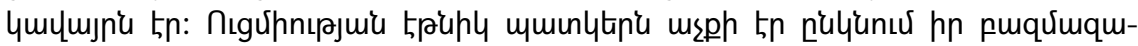

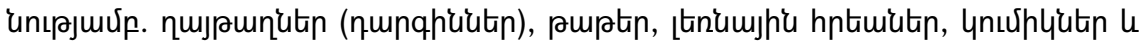
uృ $u$ :

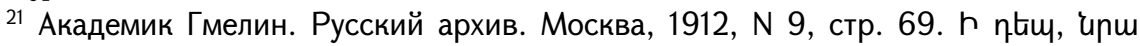

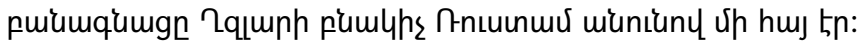

${ }^{22}$ Академик Гмелин, стр. 70-72.

${ }^{23}$ Unyju untinnư, $t_{2} 71$ :

24 unıju untnnuu, t2 74: 


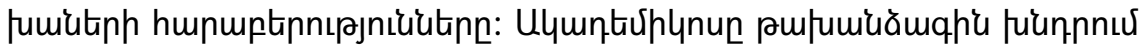

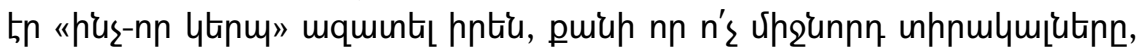

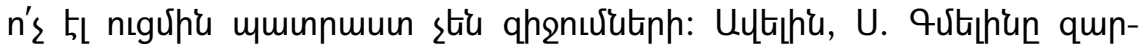

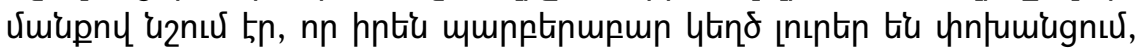

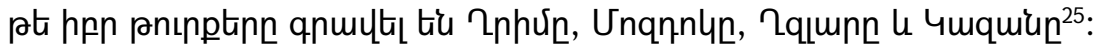

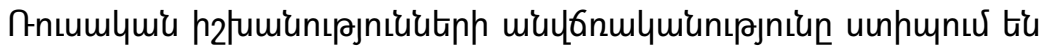

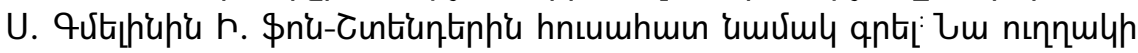

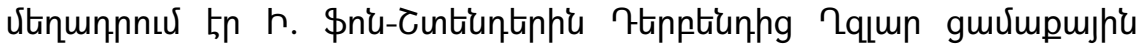

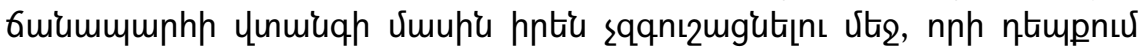

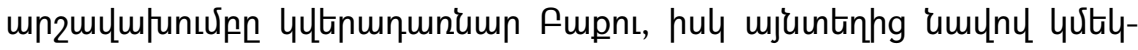

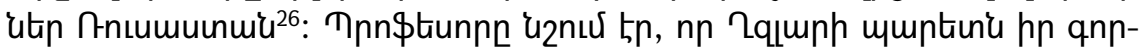

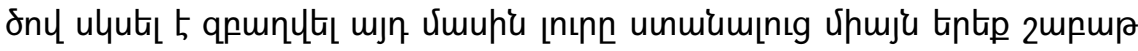
ming 27 :

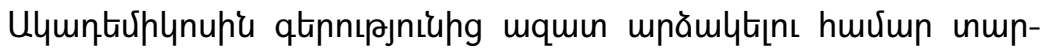

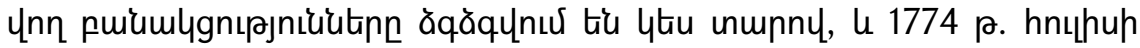

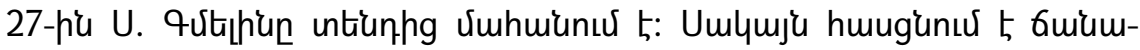

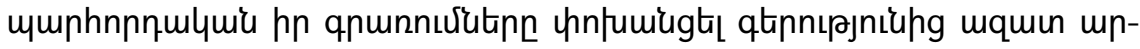

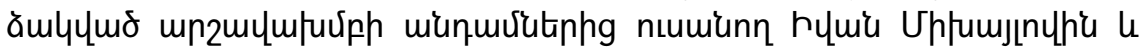

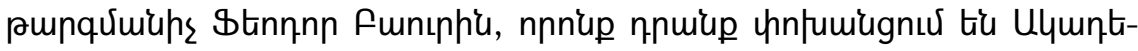
uhump huiuăumornnnuhu:

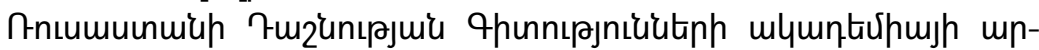

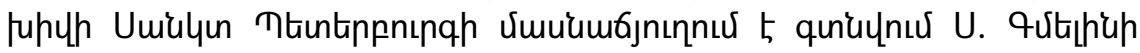

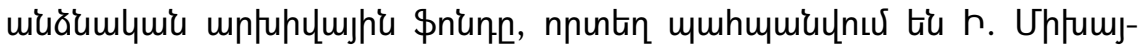

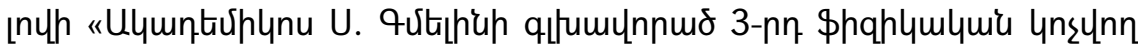

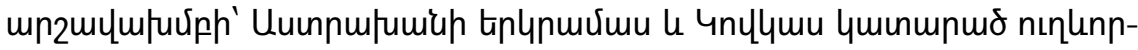

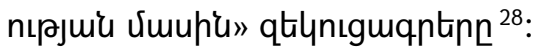

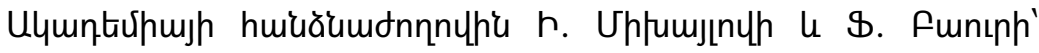

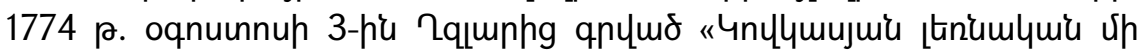

\footnotetext{
${ }^{25}$ Академик Гмелин, стр. 74-75.

${ }^{26}$ Unı'u untinnư, 52 76, 77:

27 Unıju untinnư, 52 76:

28 Рапорты студента переводчика Ивана Михайлова о 3-ей „физической экспедиции" акад. С. Г. Гмелина в Астраханский край и на Кавказ, 1774-1775 гг., СПФ АРАН, Ф. 3, Оп. 34, д. 32, лл. 1-41.
} 


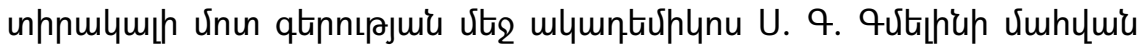

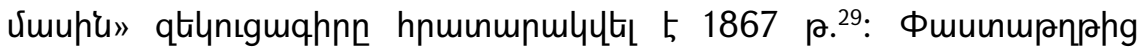

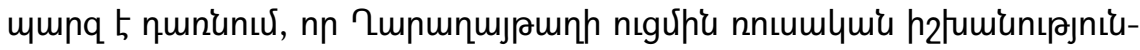

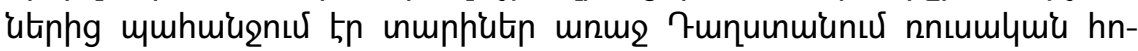

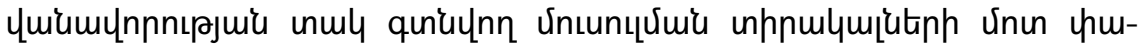

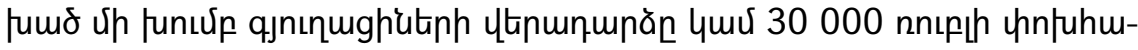

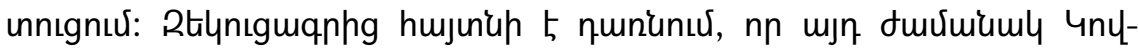

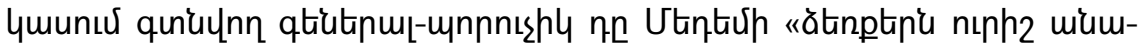

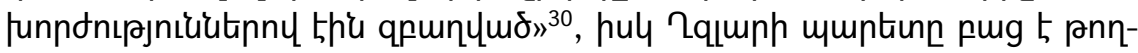

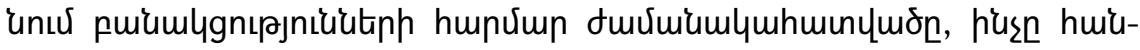

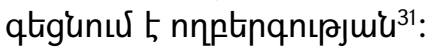

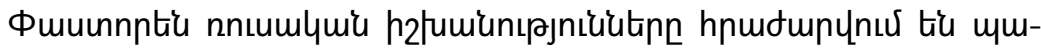

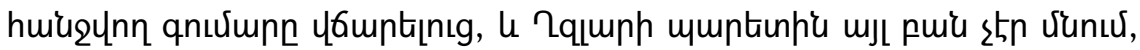

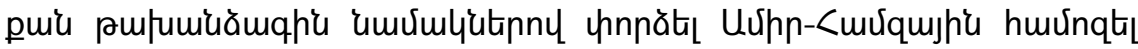

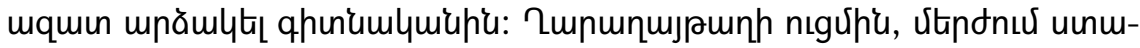

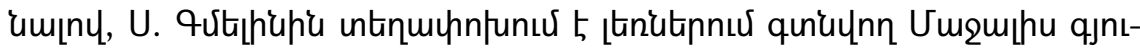

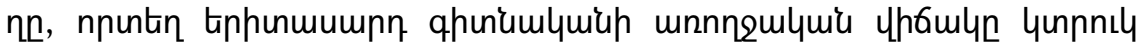

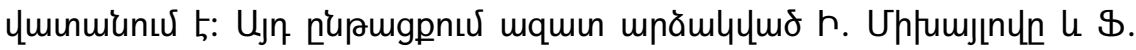

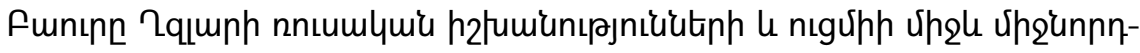

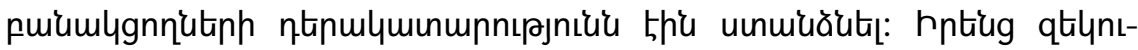

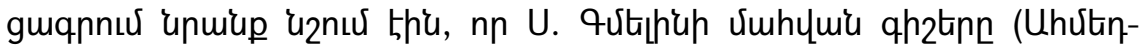

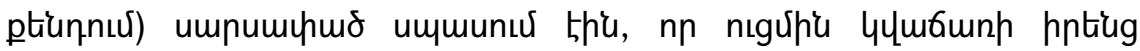

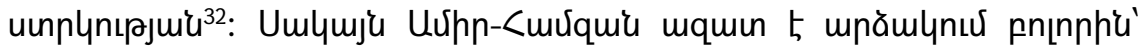

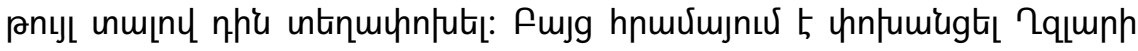

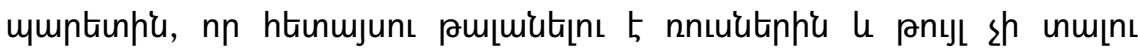

29 О смерти академика С. Г. Г. Гмелина в плену у одного горского кавказского владетеля. Чтения в императорском обществе истории и древностей российских при московском университете, 1867, июль-сентябрь, кн. 3-я, Москва, 1867, стр. 11-16.

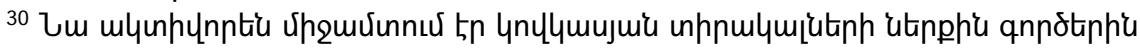

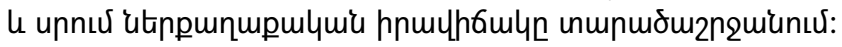

${ }^{31}$ О смерти академика С. Г. Г. Гмелина в плену у одного горского кавказского владетеля, стр. 11.

32 Unıju untinnıu, to 13-14: 


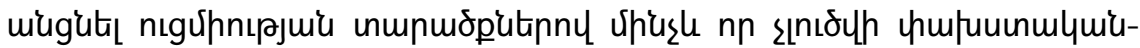
utiph hungn ${ }^{33}$ :

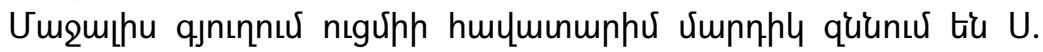

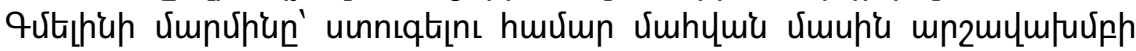

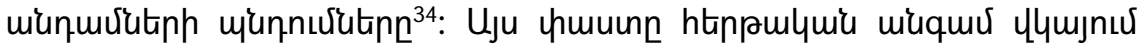

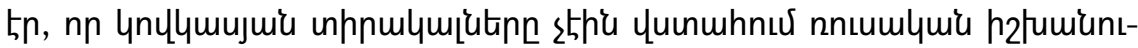
moniuktinhiu:

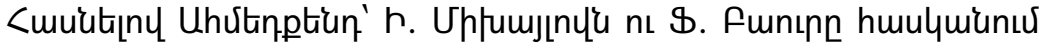

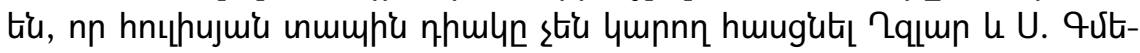

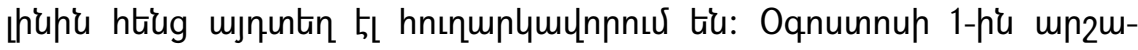

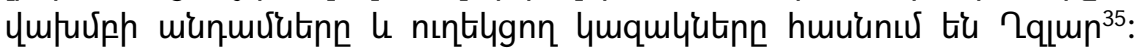

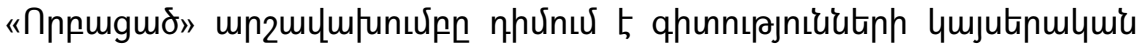

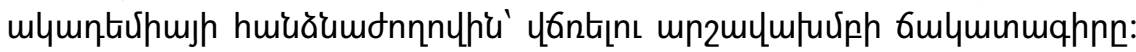

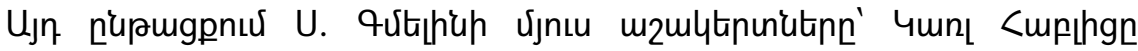

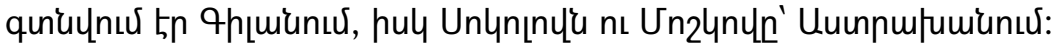

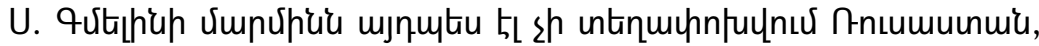

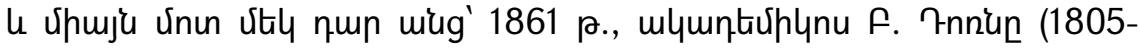

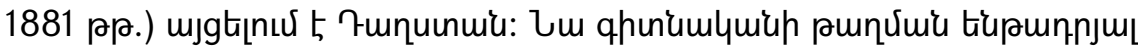

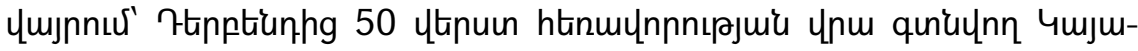

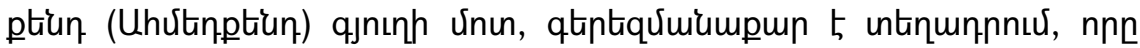
1903 p. \thnulquiuquulnuर t:

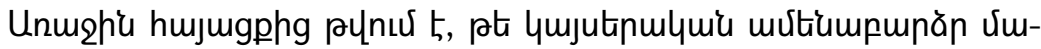

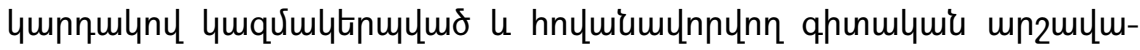

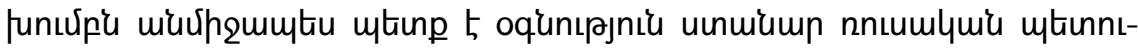

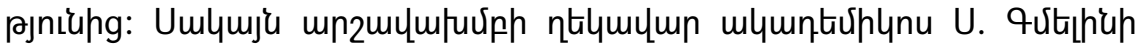

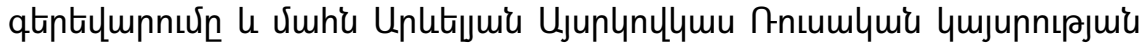

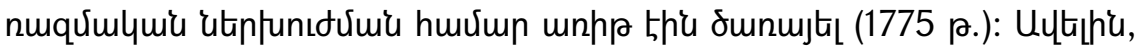

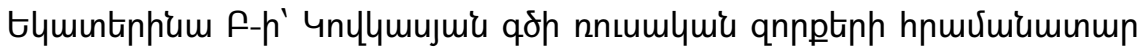

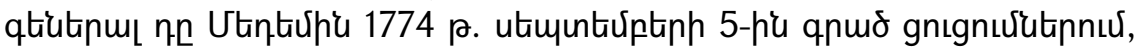

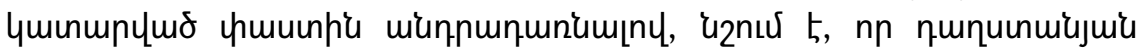

\footnotetext{
33 乙nıృ untinnux, 52 14:

34 Unııu untinnux:

35 О смерти академика С. Г. Г. Гмелина в плену у одного горского кавказского владетеля, стр. 14.
} 


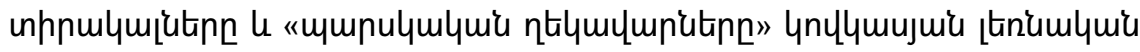

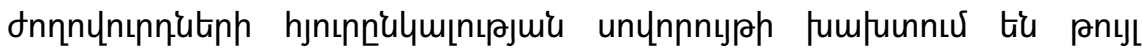

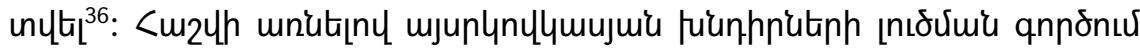

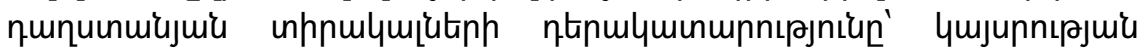

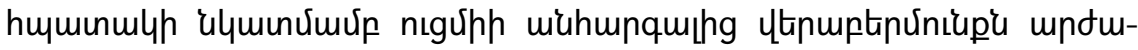

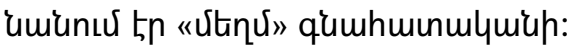

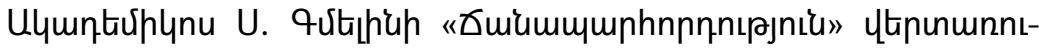

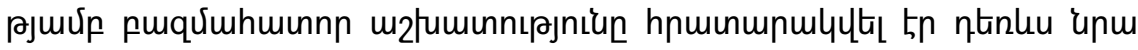

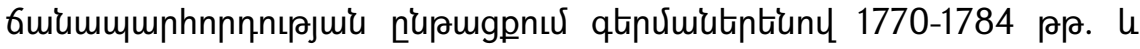

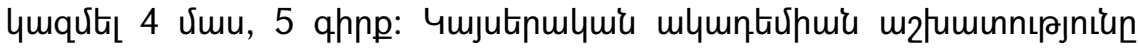

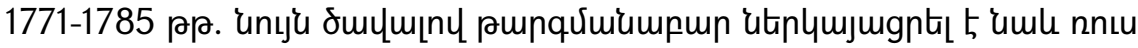
nuptingnnhu:

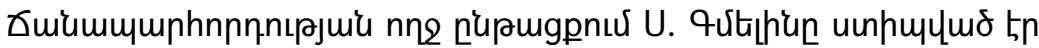

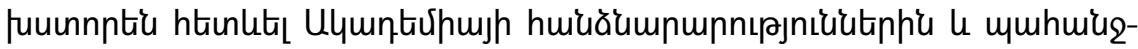

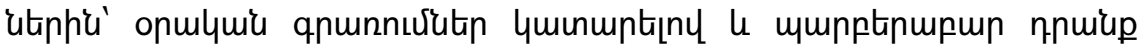

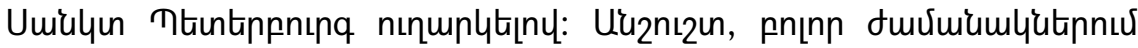

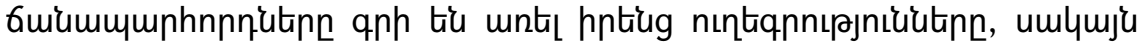

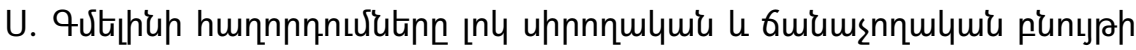

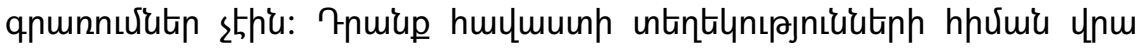

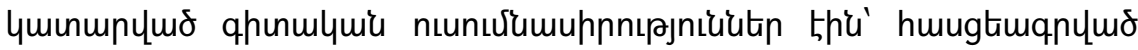

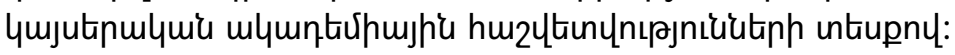

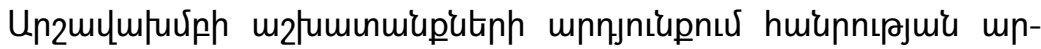

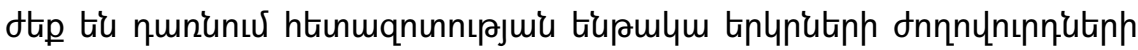

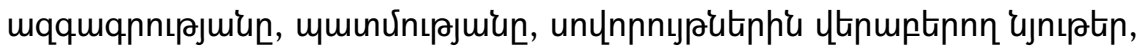

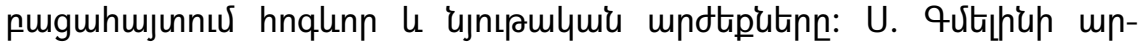

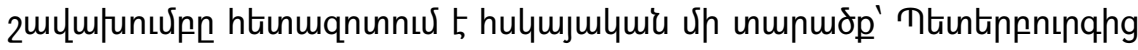

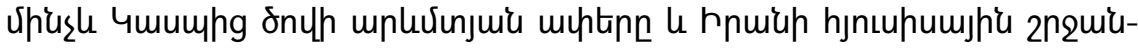

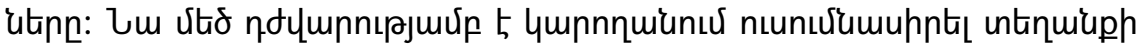

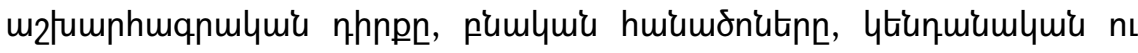

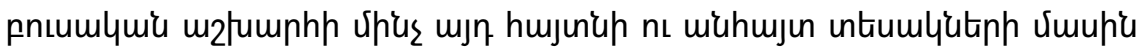

${ }_{36}$ Сборник Императорского русского исторического общества, т. 135, СПб., 1911, стр. 210. 


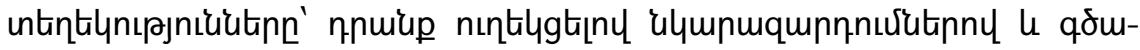
umunltinutinny:

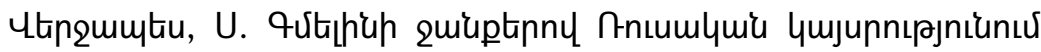

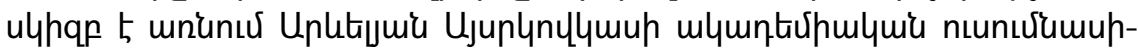

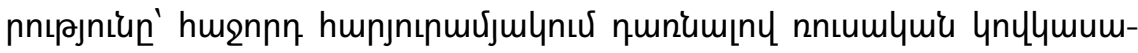
qhunnıрjuiu hpúptiphg uttlun:

\section{MKHITARYAN GOHAR}

\section{S. GMELIN'S TRAVEL TO THE EASTERN TRANSCAUCASIA AND NORTHERN REGIONS OF IRAN}

During the Russo-Turkish War (1768-1774) the expedition organized by the Russian Imperial Academy of Sciences building in Saint Petersburg, in the person of S. Gmelin, for research purposes explored the western shores of the Caspian Sea and the northern regions of Iran. As a result of their research, the ethnography, history and the materials on the customs of the people of these territories are accepted as public value, the spiritual and material values are revealed as well.

During the study of the northern provinces of Iran and the Eastern Transcaucasia the expedition had to overcome many obstacles by putting S. Gmelin's life on the line. 